ACTA MYCOLOGICA

Vol. 36 (2): $257-272$

2001

\title{
Stimulation of Armillaria rhizomorph growth by oak root fungi
}

HANNA KWASNA ${ }^{1}$, URSZULA KOTYNSKA ${ }^{1}$, PIOTR LAKOMY ${ }^{1}$ and KEN MALLETT ${ }^{2}$

${ }^{t}$ Departmeat of Fores: Pathology. A. Cieszkowski Agricultural University

Wojska Polskiego 71 c, PL-60.625 Poznan, Poland

e-mait kwasna@owl.au.poman.pl

${ }^{2}$ Canadian Forest Service, Northem Forestry Center

$5320122 \mathrm{St}$, Edmonton, Alberta T6H 3S5, Canada

K waśna H. Kotyniska U., Lak omy P., Mallett K. Stumulation of Armillaria rhizomarph growth by oak root fungi Acta Mycol. 36 (2): 257-272, 2001.

Thirly one different genera of fungi were isolated from the wood of roots of 50-year-old oak (Qwercus robur). The most frequently isclated fungi were: Myceliuen radicis atroviress alpha (MRAA), Clonosiachys sp. and Penicillion daleae. Beauperia bassiana, Clanostachys sp., Cryprosporiopsis radicicola, Geoirichum candidum, Mortierella vinacea, MRAA, P. daleae, P. janczewskll. P. spimulosum. Sporothrix schenckii and Tolypockadium niveutn significantly cnhanoed Armillaria mellea thizomorph initiation and growth from oak branch segments in vitro. The biggest stimulation effect was noticed when the dematiaceous hyphonycetes, e.g. MRAA, $P$. dimorphospora and $S$. schenckil were studied.

Key words: Armillaria mellea, Armillaria ostoyae, Quereus robur, microfungi, roots.

\section{INTRODUCTION}

Armillaria species cause root disease and butt rot of many economically important forest tree species throughout the world (Wargo and Shaw 1985). In the Northern hemisphere Armillaria ostoyae (Romagn.) Herink is the most often associated with Armillaria root disease in conifers, and A. mellea (Vahl: Fr.) Kummer with disease of broadleaved trees rather than conifers (Kile et al. 1991; Guillaumin et al. 1993; Ota ct al. 1998).

In Poland Armillaria butt and root rot occurs on 156608 ha of broadleaved and coniferous forests, mainly in the south and north-east (A nonymous 1998). Armillaria ostoyae is the principal species recorded. It causes severe losses particularly in young Scots pines (20 415 ha of $10-20$ year-old stands) planted often in/after mixed stands. Armillaria mellea occurs more rarely. There are only single records on its occurrence (Źólciak 1999 a, b), but intensive 
studies on the distribution of different Armillaria species in Poland are carried out.

Armillaria infects trees either by rhizomorph penetration of healthy roots or through physical contact of a suscept root with a diseased root. Rhizomorphs are important in dissemination and survival of the pathogen. During infection rhizomorphs penetrate the bark and form mycelial fans, which spread within the inner bark and cambium of the host root.

The common occurrence of Armillaria basidiomes at the bottom of trunks, and rhizomorphs on roots and butts of discased oaks in mixed Scots pine (Pinus sylvestris) - oak (Quercus robur) stands shows that diseased oak may serve as a food base for Armillaria, from where rhizomorphs grow and attack healthy trees continuously.

Fungi and their metabolites may inhibit or stimulate Armillaria growth and rhizomorph formation in the field. Trichoderma spp. and a few members of Basidiomycotina may inhibit the rhizomorph production or prevent colonization of woody material ( $\mathrm{H} \mathrm{a} \mathrm{g} \mathrm{l} \mathrm{e} \mathrm{and} \mathrm{S}$ h a w 1991). Other fungi, e.g. Mycelium radicis atrovirens Melin (M a ń k a 1953), Aureobasidium pullulans (de Bary) Arnaud (P e n t 1 a n d 1965, 1967), Macrophoma, Gliocephalis, Diplodia, Sordaria (W a t a n a be 1986), Zygorhynchus moelleri Vuill. ( $\mathrm{W}$ w a $\dot{\mathrm{n}}$ a and $\mathrm{L}$ a k o $\mathrm{m}$ y 1998), and a few members of Deuteromycotina (W a $t$ a $n$ a b e 1986) may induce rhizomorph formation.

The purpose of the study was to determine the effect of the most commonly occurring fungi in oak ( $Q$. robur) roots on the initiation and growth of $A$. ostoyae and A. mellea rhizomorph in vitro. Armillaria ostoyae and A. mellea were choscn for studies due to their host specialization. Generally, in Europe, A. mellea can infect vigorous oak trees, and $A$. ostoyae can colonize oaks, when growing within diseased conifer stands, particularly when their resistance is reduced by suppression ( $\mathrm{G}$ u i $11 \mathrm{a}$ u $\mathrm{m}$ i n and $\mathrm{L}$ u n g 1985; R i s h be th 1985 b; Roll- H a n s en 1985; D a vidson and $R$ is h bet $h$ 1988).

\section{MATERIALS AND METHODS}

I s o l a t e s. The fungi were isolated from the root wood of the common oak $(Q$. robur $)$ trees found in mixed stand with $S$ cots pine $(P . s y l v e s t r i s)$ affected by A. ostoyae. The roots were collected from 5 , randomly selected, apparently healthy 50-year-old co-dominant oaks within a $30 \times 50 \mathrm{~m}$ area in the Huta Pusta Forest District (western Poland, $17^{\circ} 10^{\prime}$ E, $52^{\circ} 50$ N) division $131 \mathrm{~d}$. Three roots of approximately $30 \mathrm{~cm}$ length and $5-10 \mathrm{~mm}$ in diameter werc excavated from the $\mathrm{A}-$ soil horizon around each of the 5 trees. The roots were kept at $4^{\circ} \mathrm{C}$ until they were washed under running water and $2-3$ randomly selected segments of $10 \mathrm{~mm}$ length were excised per root. Segments were gerially washed 10 times for 3 minutes in sterile, distilled water. The bark was removed aseptically with a scalpel and wood from each segment was aseptically cut into $1 \mathrm{~mm}$ thick discs (sub-segments). The sub-segment wood was placed 
onto the surface of $2 \%$ malt extract agar $\left(20 \mathrm{~g} \mathrm{Difco}{ }^{(\mathrm{R})}\right.$ malt extract, $15 \mathrm{~g}$ agar, $0.1 \mathrm{~g}$ streptomycin sulphate, 11 distilled water) and sclective nutrition

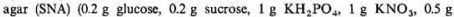
$\mathrm{MgSO}_{4} \times 7 \mathrm{H}_{2} \mathrm{O}, 0.5 \mathrm{~g} \mathrm{KCl}, 15 \mathrm{~g}$ agar, $0.1 \mathrm{~g}$ streptomycin sulphate, 11 distilled water), ( $\mathrm{N}$ i r e n be r g 1976). A total of 180 sub-segments (36 per tree) were put onto each medium in 30 Petri dishes $(90 \mathrm{~mm} \times 15 \mathrm{~mm})$ and incubated at $22^{\circ} \mathrm{C}$ for $10-12$ days in daylight. The plates were examined microscopically and sporulating fungi (mostly on SNA) were identified. Non-sporulating colonies arising from the sub-segments were transferred to potato dextrose agar ( $39 \mathrm{~g} \mathrm{Difco}{ }^{(\mathbf{R})}$ PDA, 11 distilled water) slants and incubated at room temperature under diffused daylight until sporulation occurred. Some dematiaceous hyphomycetes were induced to sporulate under UV light (310-420 nm for $12 \mathrm{~b}$ a day) at $20^{\circ} \mathrm{C}$, or on $2 \%$ malt extract agar kept at $5^{\circ} \mathrm{C}$ in high humidity for $12-15$ months. The frequency of colonization by particular fungal species was defined as the percentage of isolation of the fungus from sub-segments on both media. The isolated fungi are hereafter referred as the 'test' fungi.

The $A$. ostoyae isolates $(94125,94126)$ were obtained from basidiomes fruiting in severely discased 6-year-old Scots pine at Jamy Forest District (Poland $18^{\circ} 50^{\prime} \mathrm{E}, 53^{\circ} 38 \mathrm{~N}$ ). These two isolates were selected because in experiment on rhizomorph production by diferent genotypes of $A$. ostoyae, 94 125 produced the lowest and 94126 the highest number of rhizomorphs in culture. The A. mellea isolates $(94056,94080)$ were obtained from basidiomes fruiting on the $Q$. petraea Liebl., and Juglans regia L. in Ursa and Soprow (Hungary), respectively. Polish isolates of $A$. mellea were unavailable at the time of the study.

$\mathrm{Grow}$ th in o k seg men ts. Freshly cut live branches segments ( $2 \mathrm{~cm}$ in diameter) of 20-year-old $Q$. robur were cut into $1-\mathrm{cm}$ long discs, and $5-\mathrm{cm}$ long lengths, washed with $70 \%$ ethanol and autoclaved twice at $121^{\circ} \mathrm{C}$ for $60 \mathrm{~min}$. The $1 \mathrm{~cm}$ long discs were immersed into cultures of $A$. ostoyae or $A$. mellea growing on $8 \%$ malt agar (as above with $8 \%$ Difco ${ }^{\odot}$ malt extract) and incubated in the dark for 30 days at $22^{\circ} \mathrm{C}$. The $5 \mathrm{~cm}$ long oak segments were inoculated with 'test' fungi by immersing the segment in a jar containing a fungal culture growing on PDA at the bottom. Jars were filled with wet, sterilized sand, closed and left for 2 months in the dark at $22^{\circ} \mathrm{C}$. When the $1 \mathrm{~cm}$ long discs were covered with thin mats of white-cream to light brown Armillaria mycelium (after 30 days of incubation) they were used to inoculate the $5 \mathrm{~cm}$ long segments infested by the root fungi. Dises and segments were joined by nailing them together with $2 \mathrm{~cm}$ long nails. The control treatment consisted of a sterile branch segments attached to Armillaria infested discs. Joined dises and segments were put into wet, sterilize sand in jars and incubated in the dark at $22^{\circ} \mathrm{C}$. After 2 months, when the Armillaria species in the control segments were well established, all segments (control and 'test' fungi/Armillaria spp. infested) were carefully removed from jars and inserted 
into plastic bags containing $0.7 \mathrm{~kg}$ of a substrate consisting of forest soil, sand, peat and humus (1:1:1:1). After 2 months at $22^{\circ} \mathrm{C}$, the number of rhizomorphs, their length, number of living initials, and dry weight were assessed. Each 'test' fungus/Armillaria species treatment and the control treatment were replicated four times.

Grow th in cult u r e. Two inocula ( $3 \mathrm{~mm}$ diameter plugs cut from the margin of 2-wcck-old colonies on $2 \%$ malt agar); one of a 'test' fungus, and the other of $A$. ostoyae or $A$. mellea were placed on $2 \%$ malt agar in the centre of a Petri dish at $2 \mathrm{~cm}$ distance. Each 'test' fungus, and $A$, ostoyae and $A$. mellea also were grown separately as controls. Cultures were incubated for 28 days at $23^{\circ} \mathrm{C}$. Each two-fungal culture and the control treatment were replicated four times. The fungal interactions were estimated using the scoring system developed by $\mathrm{M}$ a ń $\mathrm{k}$ a et al. (1991). A final score of a two-fungi culture included the number of points allocated for the surrounding of a colony, the inhibition zone between two colonies, and the change in colony size.

ANOVA and analysis of variance of ranks with the Kruskal-Wallis test were used for evaluation of the effects of 'test' fungi on $A$. mellea and A. ostoyae rhizomorph production, respectively. Multiple comparison analysis was used to evaluate differences between treatments (S i g m a S t a t. 1995).

\section{RESULTS}

F u n g i. 136 isolates of fungi belonging to 31 genera were isolated from 360 Q robur root sub-segments plated on $2 \%$ malt agar and selective nutrition agar (SNA) (Table 1). The media did not scem to effect the number or species of fungi isolated, (65 isolates on $2 \%$ malt agar, and 71 on SNA) nor did they influence the vegetative growth of specific fungi. Selective nutrition agar (SNA), howcver, stimulated the sporulation of a few species, e.g. Clonostachys sp., Cryptosporiopsis radicicola and Phialocephala dimorphospora.

The most frequently isolated species was a non-sporulating dematiaccous hyphomycete - Mycelium radicis atrovirens alpha (MRAA) type 1 and 2, which accounted for more than 46 of the total number of isolates. MRAA - type 1 included fungi with grayish - brownish - black mycelium, partly encrusted and coiled hyphae, which often formed the thick funicles. MRRA - type 2 included fungi with distinctly black mycelium, rarely encrusted and coilcd, single (never in funicles) hyphae, and distinct right-angled hyphal branching (M c l in 1921, 1923). Only the single isolate of dematiaceous hyphomycete produced phialoconidia in dark, after 15 months at $5^{\circ} \mathrm{C}$, and this was identified as $\boldsymbol{P}$. dimorphospora. None of the MRAA types produced brown soluble pigment suggesting $M . r$. atrovirens beta (M e 1 i n 1923; L e v i s o h n 1960).

The second most abundant fungus was Clonostachys sp, which accounted for $16.9 \%$ of all isolates. This fungus produced white, cream or pink, slow growing colonies, with many encrusted hyphae in the acrial mycelium and 
T a b I e 1

Fungi isolated from root segments of Quercus robur

\begin{tabular}{|c|c|}
\hline Species of fungus & Frequency $(\%)$ in fungal assemblage \\
\hline Mycelium radicis atrovirens alpha (1) & 346 \\
\hline Clonostachys sp. & 169 \\
\hline Mycelium radicis atroyirens alpha (2) & 11.8 \\
\hline Penicilliwm daleae Zaleski & 6.6 \\
\hline Peniciltium janczewskii Zaleski & 3.7 \\
\hline Tolypocladium niveum (Rostrup) Bissett & 3.7 \\
\hline Sporothrix sehenckit Hektoea et Perkins & 2.2 \\
\hline Cryplosporiopsis radicicola Kowalski et Bartnik & 1.5 \\
\hline Georrichum candidaum Link & 1.5 \\
\hline Mortierella wiracea Dixon-Stewart & 1.5 \\
\hline Penicillitum cilrinum Thom & 1.5 \\
\hline Penicillitum herquei Bainicr et Sartory & 1.5 \\
\hline Beauveria bassiana (Balsamo) Vuill. & 0.7 \\
\hline Penicilliwn spinulosum Thom & 0.7 \\
\hline Phielocephtala dimorphospora Kendrick & 0.7 \\
\hline Total number of isolates (ineluding rare species) & 136 \\
\hline
\end{tabular}

Rare spceics isolated only from one too! segment: Botrytis cinerea Pers, Chrysosporium merdarium (Link) J. Carm., Exophiala jeanselmei (Langeron) MeGinnis et Padbybe, Exophiala sp. Heierohasfidion annosum (Fr.) Bref., Mortierella gracilis Linn., $M$ microspora Wolf. var. macrocystis (Gams) Linn., Mortierella schulteri (Sacc.) de Hoog. Trichoderma koningï Oudem, stesile dematiaceous hyphomyeetes-8 species.

dimorphic conidiophores. Primary conidiophores were solitary, verticillate to more-level verticillate, with compressed branches and phialides forming a slender penicillus, with stipes usually longer than penicillus, but sometimes short and bearing long branches. Secondary conidiophores were solitary or loosely aggregated, with stipe not considerably longer than the penicillus. Penicilli were bi- to quaterverticillate with compressed branches forming imbricate chains of conidia, which, on SNA after 3 months incubation at $5^{\circ} \mathrm{C}$, cohered in round colourless to white, watery, globose slimy masses. Conidia were oblong, slightly curved with one end broadly rounded, and measured $4.5-8 \times 2-4$ $\mu \mathrm{m}$. The morphology was similar irrespective of the colony colour. Penicillium species accounted for $15 \%$ of all isolates. The most common were $P$. daleae, $P$. janczewskii and $P$. citrinum. The remaining $22 \%$ were other fungi belonging to 26 different genera.

Rhizomorph formation by Armillaria influc nced by ' $\mathrm{est}$ ' fungi. The 'test' fungi did have an effect on rhizomorph charactcristics of $A$. mellea. Beauveria bassiana, Clonostachys sp., C. radicicola, Geotrichum candidum, Mortierella vinacea, MRAA, P. daleae, P. janczewskii, $P$. spinulosum, Sporothrix schenckii, and Tolypocladium niveum significantly $(P \leqslant 0.05, P \leqslant 0.01)$ enhanced number of rhizomorphs, number of rhizomorph initials, rhizomorph length and weight of A. mellea 94080 when they were growing from oak branch segments (Table 2). Mortierella vinacea. 
$\mathrm{T}$ a b I c 2

The effect of fungi isolated form Quercus robur on rhizomorph production of Armillaria estoyae and $A$. mellea

\begin{tabular}{|c|c|c|c|c|c|}
\hline Treatment & $\begin{array}{c}\text { Armillaria species } \\
\text { (isolate) }\end{array}$ & $\begin{array}{l}\text { Number of } \\
\text { thizomorehs }\end{array}$ & $\begin{array}{c}\text { Number of } \\
\text { rhizomorph } \\
\text { initials }\end{array}$ & $\begin{array}{l}\text { Rhizomorph } \\
\text { length (mm) }\end{array}$ & $\begin{array}{l}\text { Rhizomorph } \\
\text { weight (mg) }\end{array}$ \\
\hline $\begin{array}{l}\text { Control } \\
\text { (Armillaria spp. } \\
\text { alone) }\end{array}$ & $\begin{array}{l}\text { A. astoyae } 94125 \\
\text { A. ostoyae } 94126 \\
\text { A. mellea } 94056 \\
\text { A. mellea } 94080\end{array}$ & $\begin{array}{l}0 \\
0 \\
4.25 \\
3.0\end{array}$ & $\begin{array}{l}0 \\
0 \\
5.25 \\
3.0\end{array}$ & $\begin{array}{c}0 \\
0 \\
58.75 \\
32.25\end{array}$ & $\begin{array}{l}0 \\
0 \\
5.25 \\
3.50\end{array}$ \\
\hline Beauveria bessiana & $\begin{array}{l}\text { A. osioyae } 94 \quad 125 \\
\text { A. osioyae } 94126 \\
\text { A. mellea } 94056 \\
\text { A. mellea } 94080\end{array}$ & $\begin{array}{l}0 \\
0 \\
3.75 \\
9.75\end{array}$ & $\begin{array}{c}0 \\
0 \\
3.75 \\
12.25\end{array}$ & $\begin{array}{c}0 \\
0 \\
25.0^{\circ} \\
174.0^{\circ}\end{array}$ & $\begin{array}{l}0 \\
0 \\
1.75 \\
21.0^{*}\end{array}$ \\
\hline Clonostachys sp. & $\begin{array}{l}\text { A. ostoyae } 94125 \\
\text { A. osioyae } 94126 \\
\text { A. mellea } 94056 \\
\text { A. mellea } 94080\end{array}$ & $\begin{array}{l}0 \\
0 \\
7.25 \\
11.0^{\circ} \\
\end{array}$ & $\begin{array}{l}0 \\
0 \\
7.75 \\
13.50^{\circ}\end{array}$ & $\begin{array}{l}0 \\
0 \\
57.50 \\
196.25 *\end{array}$ & $\begin{array}{l}0 \\
0 \\
3.50 \\
18.0^{\circ}\end{array}$ \\
\hline $\begin{array}{l}\text { Cryplosporiopsis } \\
\text { radicicola }\end{array}$ & $\begin{array}{l}\text { A. astoyae } 94125 \\
\text { A. astoyae } 94126 \\
\text { A. mellea } 94056 \\
\text { A. mellea } 94080\end{array}$ & $\begin{array}{l}0 \\
0 \\
2.0 \\
12.0\end{array}$ & $\begin{array}{l}0 \\
0 \\
2.75 \\
14.25\end{array}$ & $\begin{array}{l}0 \\
0 \\
53.75 \\
265.0^{\circ}\end{array}$ & $\begin{array}{l}0 \\
0 \\
5.0 \\
22.50\end{array}$ \\
\hline $\begin{array}{l}\text { Geotrichum } \\
\text { candidatim }\end{array}$ & $\begin{array}{l}\text { A. astoyae } 94125 \\
\text { A. asioyae } 94126 \\
\text { A. mellea } 94056 \\
\text { A. mellea } 94080\end{array}$ & $\begin{array}{l}0 \\
0 \\
1.75 \\
12.5 *\end{array}$ & $\begin{array}{l}0 \\
0 \\
1.75 \\
19.25 \bullet\end{array}$ & $\begin{array}{l}0 \\
0 \\
30.0 \\
255.0=\end{array}$ & $\begin{array}{l}0 \\
0 \\
3.50 \\
34.75 \cdots\end{array}$ \\
\hline Mortierella vinacea & $\begin{array}{l}\text { A. astoyae } 94125 \\
\text { A. asioyoe } 94126 \\
\text { A. mellea } 94056 \\
\text { A. mellea } 94090\end{array}$ & $\begin{array}{l}1.0 \\
0 \\
10.0^{*} \\
16.0^{\circ}\end{array}$ & $\begin{array}{l}11.25 \\
0 \\
12.0^{\circ} \\
19.0^{\circ}\end{array}$ & $\begin{array}{l}0.75 \\
0 \\
155.0 * \bullet \\
183.75 *\end{array}$ & $\begin{array}{c}0 \\
15.5^{*} \\
27.5^{\bullet \bullet}\end{array}$ \\
\hline $\begin{array}{l}\text { Mycelium radicis } \\
\text { atrovirens (1) }\end{array}$ & $\begin{array}{l}\text { A. ostoyae } 94125 \\
\text { A. ostoyae } 94126 \\
\text { A. mellea } 94056 \\
\text { A. mellea } 94080\end{array}$ & $\begin{array}{l}0.25 \\
0.50 \\
6.0 \\
2.50\end{array}$ & $\begin{array}{l}0.25 \\
0.50 \\
6.50 \\
3.50\end{array}$ & $\begin{array}{c}21.25 \\
6.25 \\
97.50^{*} \\
83.75^{*}\end{array}$ & $\begin{array}{l}3.75 \\
1.25 \\
6.25 \\
5.25\end{array}$ \\
\hline $\begin{array}{l}\text { Mycelium radicis } \\
\text { atrovirens (2) }\end{array}$ & $\begin{array}{l}\text { A. osioyae } 94125 \\
\text { A. osioyae } 94126 \\
\text { A. mellea } 94055 \\
\text { A. mellea } 94080\end{array}$ & $\begin{array}{l}2.25 * \\
0 \\
17.25 * \\
7.75\end{array}$ & $\begin{array}{l}2.50 \\
0 \\
19.00 * * \\
9.75^{*}\end{array}$ & $\begin{array}{l}21.25 \\
0 \\
252.50 \cdots \\
1950^{\circ}\end{array}$ & $\begin{array}{l}2.50 \\
0 \\
17.25 * 4 \\
20.0^{* *}\end{array}$ \\
\hline Penicillium ciurinum & $\begin{array}{l}\text { A. osioyae } 94125 \\
\text { A. ostoyae } 94126 \\
\text { A. mellea } 94056 \\
\text { A. mellea } 94080\end{array}$ & $\begin{array}{l}0.25 \\
1.75 \\
3.50 \\
5.25\end{array}$ & $\begin{array}{l}0.25 \\
1.75 \\
4.50 \\
5.75\end{array}$ & $\begin{array}{l}8.75 \\
40.0 \\
70.0 \\
95.0\end{array}$ & $\begin{array}{c}0.50 \\
5.0 \\
11.75 \\
8.25\end{array}$ \\
\hline Penicillium daleae & $\begin{array}{l}\text { A. asioyae } 94125 \\
\text { A. osioyae } 94126 \\
\text { A. mellea } 94056 \\
\text { A. mellea } 94080\end{array}$ & $\begin{array}{l}0 \\
2.75 \\
10.0^{*} \\
10.75\end{array}$ & 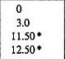 & $\begin{array}{l}0 \\
31.25^{\circ} \\
157.50^{\circ} \\
187.50^{\circ}\end{array}$ & $\begin{array}{l}0 \\
4.52 \\
9.0 \\
13.75\end{array}$ \\
\hline
\end{tabular}




\begin{tabular}{|c|c|c|c|c|c|}
\hline Penicillium herquei & $\begin{array}{l}\text { A. astoyae } 94125 \\
\text { A. astoyae } 94126 \\
\text { A. mellea } 94056 \\
\text { A. mellea } 94080\end{array}$ & $\begin{array}{l}0.25 \\
1.25 \\
3.0 \\
0\end{array}$ & $\begin{array}{l}0.25 \\
1.25 \\
4.50 \\
0\end{array}$ & $\begin{array}{c}2.75 \\
37.0 \\
54.50 \\
0\end{array}$ & $\begin{array}{r}0.25 \\
3.25 \\
17.50 \\
0\end{array}$ \\
\hline $\begin{array}{l}\text { Penicilliwn } \\
\text { janezewskii }\end{array}$ & $\begin{array}{l}\text { A. ostoyae } 94125 \\
\text { A. ostoyae } 94 \quad 126 \\
\text { A. mellea } 94056 \\
\text { A. mellea } 94080\end{array}$ & $\begin{array}{l}0 \\
1.75 \\
2.0 \\
9.0\end{array}$ & $\begin{array}{l}0 \\
1.75 \\
2.0 \\
10.75 * *\end{array}$ & $\begin{array}{l}0 \\
23.50^{\bullet} \\
23.0 \\
268.75 \bullet\end{array}$ & $\begin{array}{l}0 \\
1.25 \\
1.75 \\
22.75\end{array}$ \\
\hline $\begin{array}{l}\text { Penicillium } \\
\text { spinulosum }\end{array}$ & $\begin{array}{l}\text { A. ostoyae } 94125 \\
\text { A. ostoyae } 94126 \\
\text { A. mellea } 94056 \\
\text { A. mellea } 94080\end{array}$ & $\begin{array}{l}1.0 \\
0 \\
14.75 * \\
11.50 \cdots\end{array}$ & $\begin{array}{l}1.0 \\
0 \\
18.25 * \\
13.75 * 0\end{array}$ & $\begin{array}{l}6.0 \\
0 \\
241.25 \cdots \\
162.5 * \bullet\end{array}$ & $\begin{array}{l}1.25 \\
0 \\
19.25 * 0 \\
13.25 \bullet\end{array}$ \\
\hline $\begin{array}{l}\text { Phialacephala } \\
\text { dimorphospara }\end{array}$ & $\begin{array}{l}\text { A. astoyaz } 94125 \\
\text { A. astoyae } 94126 \\
\text { A. mellea } 94056 \\
\text { A. mellea } 94080\end{array}$ & $\begin{array}{l}0.50 \\
0.25 \\
8.25 \\
4.50\end{array}$ & $\begin{array}{c}0.75 \\
0.25 \\
10.0 \\
5.25\end{array}$ & $\begin{array}{c}7.50 \\
7.50 \\
164.50^{*} \\
108.25^{\circ}\end{array}$ & $\begin{array}{r}0.75 \\
0.75 \\
11.25 \\
8.25\end{array}$ \\
\hline $\begin{array}{l}\text { Sporothrix } \\
\text { schenckii }\end{array}$ & $\begin{array}{l}\text { A. astoyae } 94125 \\
\text { A. astoyae } 94126 \\
\text { A. mellea } 94056 \\
\text { A. mellea } 94080\end{array}$ & $\begin{array}{c}0.25 \\
0.50 \\
11.25^{*} \\
12.0^{+}\end{array}$ & $\begin{array}{c}0.25 \\
0.50 \\
11.75^{*} \\
13.25^{*}\end{array}$ & $\begin{array}{l}2.50 \\
5.0 \\
150.00^{*} \\
195.0^{* 4}\end{array}$ & $\begin{array}{c}0.50 \\
0.25 \\
12.75^{\bullet} \\
17.50^{\bullet \bullet}\end{array}$ \\
\hline $\begin{array}{l}\text { Tolypocladitum } \\
\text { nivewn }\end{array}$ & $\begin{array}{l}\text { A. astayae } 94125 \\
\text { A. astoyae } 94126 \\
\text { A. mellea } 94056 \\
\text { A. mellea } 94080\end{array}$ & $\begin{array}{l}1.75 \\
1.0 \\
4.25 \\
21.25\end{array}$ & $\begin{array}{l}1.75 \\
1.0 \\
4.25 \\
28.0 * 4\end{array}$ & $\begin{array}{c}37.50^{\circ} \\
7.50 \\
75.0 \\
380.0^{* 0}\end{array}$ & $\begin{array}{c}5.0 \\
1.0 \\
10.0 \\
43.0\end{array}$ \\
\hline
\end{tabular}

Explanations: Values are means, $\mathrm{n}=4 ;{ }^{*}$ Significantly different from control at $\mathrm{P} \leqslant 0.05$; * Significantly different from control at $P \leqslant 0.01$.

MRAA 2, P. daleae, $P$. spinulosum and $S$. schenckii significantly $(\mathrm{P} \leqslant 0.05$, $\mathrm{P} \leqslant 0.01$ ) enhanced three and four rhizomorph characteristics of $A$. mellea 94 056. In control both isolates of $A$. mellea produced in average 3.6 rhizomorphs with 4.1 rhizomorph initials, $45.5 \mathrm{~mm}$ length and $4.3 \mathrm{mg}$ weight. In all treatments with 'test' fungi both isolates of $A$. mellea produced in average 8.4 rhizomorphs with 9.7 rhizomorph initials, $145.2 \mathrm{~mm}$ length and $14.1 \mathrm{mg}$ weight. Results indicate that there were statistically significant differences betwcen effects of 'test' fungi. Multiple comparison analysis based on 'test' fungi showed the statistically significant differences $(\mathrm{P} \leqslant 0.05)$ for $P$. spinulosum vs. $P$. herquei, $T$. niveum vs. $P$. herquei, and $M$. vinacea vs. $P$. herguei for rhizomorph number and number of rhizomorph initials; $M R A A(2)$ vs. $P$. herquei for rhizomorph numbers only; $T$. niveum vs. $M R A A$ (1) for thizomorph weight. Multiple comparison analysis based on $A$. mellea isolate showed that there were statistically significant differences $(\mathrm{P} \leqslant 0.05)$ between $A$. mellea 94 056 and 94080 for $C$. radicicola, $G$. candidum and $T$. niveum for all the rhizomorph characteristics; $\boldsymbol{P}$. janczewskï for rhizomorph number, number of rhizomorph initials and rhizomorph length; $B$. bassiana for number of rhizomorph initials, rhizomorph length and weight; Clonostachys sp. for 


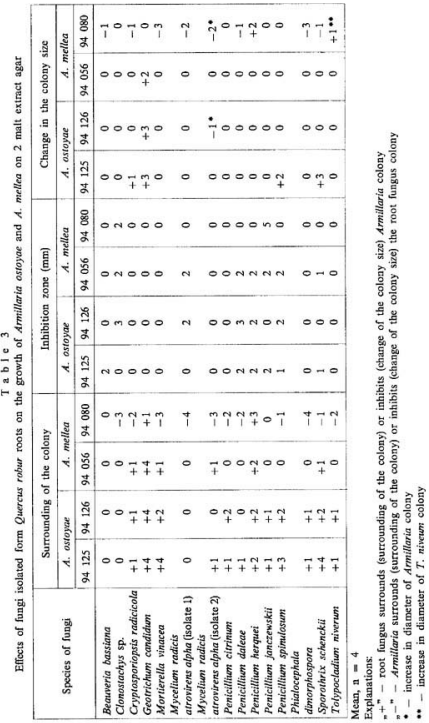


rhizomorph length and weight; and $M$. vinacea for rhizomorph weight. Rhizomorphs of $A$. mellea were produced from one or several points, mostly at the end of wood segments.

Preliminary statistical analysis showed that the data for the $A$. ostoyae rhizomorph characteristics was not 'normal' and therefore could not be analyzed by ANOVA. An analysis of variance of ranks using the KruskalWallis test showed that there was no significant difference between the 'test' fungi treatments and the control. In control A. ostoyae did not produce rhizomorphs, but only a fine mycelium under the bark. In all treatments both isolates of $A$. ostoyae produced in average 0.6 rhizomorphs with 0.6 rhizomorph initials, $9.2 \mathrm{~mm}$ length and $1.1 \mathrm{mg}$ weight. This insignificant stimulation was caused by $M$, vinacea, $M R A A, P$. citrinum, $P$. daleae, $P$. herquei, $P$. spinulosum, $P$. dimorphospora, $S$. schenckï and $T$. niveum.

Armillaria growth in culture. In two-fungi cultures on $2 \%$ malt extract agar the majority of 'test' fungi did not stimulate but rather inhibited the growth of all four isolates of Armillaria (Table 3). The inhibition resulted from (i) surrounding of Armillaria colonies (mostly of $A$. ostoyae and A. mellea 94 056; only B. bassiana. Clonostachys sp. and MRAA (1) usually grew irrespective of the presence of Armillaria), (ii) production of inhibition zone (1-5 mm wide between Armillaria and Clonostachys sp., MRAA (1), a few Penicillium spp. and S. schenckii, (iii) decrease of Armillaria colony surrounded by a 'test' fungus (only the faster growing $A$. mellea 94080 inhibited the growth of $B$. bassiana, $C$. radicicola, $M$. vinacea, $M R A A(1), P$. daleae, $P$. dimorphospora and $S$. schenckii). MRRA, P. dimorphospora and $S$. schenckii stimulated the growth of rhizomorphs in both Armillaria species. Both isolates of $A$. mellea grew faster and more profusely compared to $A$. ostoyae.

\section{DISCUSSION}

The most common microfungi found in wood of $Q$. robur roots (when $2 \%$ malt agar and SNA medium were used for isolation) were non-sporulating dematiaceous hyphomycetes belonging to $M . r$. atrovirens alpha (MRAA). $M R A A$ is considered here as a complex of two morphologically and ecologically similar taxa (M e 1 in 1921, 1923; W a ng and W i l c ox 1985). The fungus had been usually associated with ecto- endo- and pseudomycorrhizae of conifers. For many years it had never been observed in the root/soil habitat of broadleaved trees (L i n h e 11 1939; K r z e m i e n i e w s k a and B a d u r a 1954; R o bert s o n 1954; $\mathrm{H}$ a r $\mathrm{l}$ e y and $\mathrm{W}$ a id 1955; $\mathrm{M}$ a n $\mathrm{k}$ a and T ruszkowska 1958; M á́ k a 1960; G oc h c n a u $r$ and B a ckus 1967; M a ńk a et al. 1968; M orra Il and V a n ter pool 1968; N o$v a k$ and Whitting ham 1968; G o chen a r and Woodwell 1974; M orrall 1974; R i chard and Fortin 1974; Wicklow ct al. 1974; G o c he n a u 1978,1984 ; K 0 wa l s k i 1982; W a n g and Wilc ox 1985; S c h il det al. 1988; S u m me r be 111989 ; K w a s na 
1997 a, b; S a m p o et al. 1997). S u m m e r bell (1989) and K w a ś n a (1996 a; b) showed, however, that MRAA is a common, non specific, root - associated fungus in the boreal sites. Even though apparently healthy, newly formed and older, mycorrhizal and non-mycorrhizal roots frequently yield $M R A A$, it is even more commonly associated with weakened, senescent and degraded trec roots ( $R$ o b e r t s o n 1954; Living s t o n e and B 1 a s ch k c 1984; Holdenrieder and Sieber 1992) and stump roots ( $\mathrm{K}$ w a ś n a 1996 a, b). The fungus is strongly associated with tissues of root interior, and it is far less predominant in root - free soil ( $\mathrm{K}$ w a $\dot{s} \mathrm{n}$ a 1995; $1996 \mathrm{a}, \mathrm{b} ; 1997 \mathrm{a}, \mathrm{b}, \mathrm{c})$. Although $M R A A$ is often isolated from the bark of oak roots ( $\mathrm{K}$ w a $\dot{\mathrm{s}} \mathrm{n}$ a, unpublish.) it is the most commonly found in the wood of oak roots.

Clonostachys sp., the anamorph of Bionectria (S c h r o e r s et al. 1999) was detected in oak bealthy roots for the first time. It is a rare fungus, presumably with very specific nutritional preferenecs. Earlier, it had been found only on bark of dying and recently dead woody plants, less frequently on fruits, in South America and Australasia (S a m u e Is 1988). It was not previously observed in temperate climate.

The occurrence of Cryptosporiopsis radicicola in oak roots was confirmed only recently. It was one of the most frequently isolated species from roots of declining $Q$. robur in southern Poland. The fungus appears to be specific to roots although sometimes it reaches the tissues at the root collar (B a r t n i k 1989; K ow a ls ki 1991; K owa Is ki and B art n i k 1995). Its high frequency in roots of declining oaks suggests that it may be important for the health of oak. Adaptation of $C$. radicicola to roots contrasts with other Cryptosporiopsis species which occur mainly on aerial plant parts, especially on branches and trunks (B u t in 1981; K o wals k i and K e h r 1992; Su t t o n 1992; D u g a n et al. 1993).

Rhizomorphs are discrete, aggregations of hyphae that can vary in their complexity ( $\mathrm{T}$ ow n s e n d 1954). Armillaria rhizomorphs are highly developed structures with meristems, medullary and cortical cells (M o t $t$ a 1969). They are important in the infection, spread and persistance of Armillaria root discase. Abiotic factors that affect rhizomorph growth have been reviewed by $\mathrm{R}$ e dfer $\mathrm{n}$ and Filip (1991). D u m a s (1992) found several bacteria specics from forest soil capable of inhibiting $A$. gallica Marxmülier and Romagn. rhizomorph growth in culture. There is little known, however, about an effect of fungi on Armillaria rhizomorph growth or the microfungi/Armillaria interactions. The only reports on the effect of soil/root fungi are

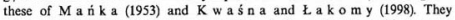
reported that $M R A A$ from spruce roots, and $Z$. moelleri from birch roots, might increase $A$. ostoyae rhizomorph formation in vitro. The stimulatory effect of A. pullulans, Diplodia, Gliocephalis, Macrophoma sp. and Sordaria on Armillaria rhizomorph production had been shown by P e n t l a n d (1965, 1967) and W a t a n a be (1986). The majority of fungi tested by them, 
however, are not being usually found in the forest soil/root habitat in Poland ( $\mathrm{K}$ w a ś n a unpubl.), and their effect on rhizomorph production cannot be taken into consideration in epidemiology of Armillaria diseasc.

This study has shown that there are several oak-root fungi that can stimulate Armillaria rhizomorph production. The stimulation of rhizomorph formation resulted in an increase of number of rhizomorphs, number of rhizomorph initials, rhizmororph length and dry weight.

The stimulation effect was statistically proven in case of $A$. mellea. The much smaller effect observed in $A$. ostoyae could be explained by duration of the experiment, which should have taken longer. It seems that both $A$. ostoyae isolates required longer than 16 weeks time for rhizomorph formation. In study of $\downarrow$ a $k$ o m y (1996) A. ostoyae produced thizomorphs after 25 weeks, and in study of K w a \& $\mathrm{n}$ a and $\mathrm{L}$ a k o m y (1998) after 8 months of growth in oak segments. The inhibition of rhizomorph formation by certain strains of $A$. ostoyae was observed also in studies of $\mathrm{G} \mathrm{u} \mathrm{i} 11 \mathrm{a} \mathrm{u} \mathrm{m} \mathrm{in} \mathrm{and} \mathrm{R} \mathrm{y} \mathrm{k} \mathrm{ow} \mathrm{s} \mathrm{k} \mathrm{i}$ (1980), R is h bet h (1985 a, b) and S i e p m a n n (1985). The degree of stimulation of 'test' fungi varied among isolates of Armillaria.

The abundant network of rhizomorph produced in forest soil, sand, peat and humus substrate by $A$. mellea, but not by $A$. ostoyae, contrasts with results of $\mathrm{R}$ i s h b e t h (1985 a), who found that $A$. mellea produced much shorter rhizomorphs from woody inocula immersed for 2 years in soil, compared to $A$. ostoyae. The tree species used for the production of woody inocula were not described by $\mathrm{R}$ is h b e $\mathrm{th}(1985 \mathrm{a})$. Differences in abilities of $A$. mellea and $A$. ostoyae to form rhizomorphs might be due to (i) the experimental method used, and to (ii) the geographical origin and variation between Armillaria isolates. Pure and sterile sand used in experiment in first two months could have distinctly inhibited the rhizomorph formation ( $G$ a r r e t t 1956; R e d f e r n 1973; R y k o w s k i 1984), which was enhanced when samples were transferred into substrate rich in nutrients.

The stimulation of rhizomorph formation in oak sections in vitro could be caused by violatile and non-violatile metabolites secreted by 'test' fungi. This thesis is supported by findings of $\mathrm{W}$ a $\mathrm{r} \mathrm{g} \mathrm{O}$ and $\mathrm{H} \mathrm{a} \mathrm{r} \mathrm{r} \mathrm{in} \mathrm{g} \mathrm{to} \mathrm{n}$ (1991) and K $w$ a s $n$ a and $\mathbf{L}$ a $k$ o m y (1998) who showed that Armillaria rhizomorph production may be stimulated by abundant volatiles produced by Ceratocystis virescens (Davids) C. Morcau, and tryptophol, which is a major secondary, non-volatile metabolite produced by $Z$. moelleri. A few 'test' fungi, e.g. $M R A A$, $P$. janczewskii and $P$. spinulosum have been shown to produce xylan- and cellulose-degrading enzymes (B äa th and Söderst ï m 1980; $\mathrm{D} \circ \mathrm{m} \mathrm{s} \mathrm{ch}$ et al. 1980). These, through the degradation of wood, may additionally favour colonization of wood by Armillaria.

The biggest stimulation of Armillaria growth and rhizomorph formation in wood sections and on malt agar was noticed when the effects of dematiaceous hyphomycetes, e.g. MRRA, $P$. dimorphospora and $S$. schenckii were tested. Melanins occurring in cell walls of these fungi are known to bind a wide variety 
of compounds including heayy metals and organic compounds ( $\mathrm{L}$ a I S S o n 1998; B u t l e r et al. 2001), and to inactivate antifungal agents in a habitat, what could make the Armillaria rhizomorph formation easier. This study introduces also a note of uncertainty to the idea that Armillaria may 'steal' precursors for melanin synthesis from accompanying fungi.

The type of interaction between Armillaria and a 'test' fungus in wood segment was only rarely related with similar type of interaction in two-culture test on agar medium. The majority of 'stimulants' of Armillaria rhizomorph formation in oak segments did not stimulate pathogen's growth on malt agar. They usually inhibited (through surrounding) $A$. ostoyae and the slower growing $A$. mellea 94056 colonics on malt agar. Only dematiaceous hyphomycetes, e.g. $M R A A, P$, dimorphospora and $S$. schenckii caused usually the simultaneous increase of Armillaria colonies growth on malt agar, and rhizomorph formation on agar and in wood. In contrast, G. candidum entirely surrounded and inhibited $A$. mellea 94056 growths on malt agar and reduced the formation of its rhizomorphs in wood. Goetrichum candidum did not also inhibit A. mellea 94080 growths on malt agar what was related with a stimulation of fungus rhizomorph production in wood (Table 2,3). This means that two-culture test may not always reflect the real interactions between fungi in wood in vitro and in vivo.

The study presents only the effect of 15 hyphomycetous fungal species. There are, however, thousands of fungal species in root/soil habitat, and it is presumed that microbial interactions are far more complex. There is no doubt, however, that the observation of rhizomorph reactions to different media, substrates and habitats, as wcll as connection of an extent of Armillaria infection with occurrence of the specific fungal communities (P r z c z b ó r $\mathrm{s} \mathrm{K} \mathrm{i}$ and $\mathrm{K}$ wa s n a 1989) suggest the fact of rhizomorph stimulation by chemical or microbiological factors.

Acknowledgements: we thank Dr Kari Korhonen (The Finnish Forest Rescarch Institute, Vantae, Finland) for providing us with both isolates of A. mellea and Pror. de S. Kowalski (Academy of Agriculture, Krakow, Poland) for his belp in identifying of Clonostachys sp.

\section{REFERENCES}

A a o n y o u 1998 . Ocena występowania ważnicj3zych szkodników i chorob infekcyjnych drzew lesnych w Polsce $w 1997$ roku oraz prognoza ich pojawu w 1998 roku, [Report on the occurrence of more important pests and infectious diseases of trees in Poland in 1997 and the progaosis of their appearance for 1998.] Instytut Bedawczy Leśnietwa, Warszawa: 1-133.

B ầ $\mathrm{t}$ h E, S ö d e r $\mathrm{s}$ t r ö m B. E. 1980. Degradation of macromolecules by mietofungi isolated from different podzolic soil horizons. Can. J. Hot. 58: 422-425.

B a r : n i k C 1989. Disease symptoms on dyiag oaks in forest distriet Jepdrzejow, Niepotomice and in Las Wolski in the years 1986 - 1987. Zeszyty Naukowe AR w Krakowie. 236: 15-33.

B utin H. 1981. Ober den Rindenbranderteger Flssiccocum quercus Oudem. and andere Rindenpilze der Eiche. Eur. J. For. Pathol, 11: 33-44.

B u $t$ I e r M. J, D z y A. W, H a s o n a J. M, M o n o y N.P. 2001. Pathogenic properties of fungal melanins. Mycologia 93: 1-8. 
Da vid s o n A. J, R is h be th J. 1938. Effect of suppression and felling on infection of oak and Scots pine by Armillaria. Eur. J. For. Pathol. 18: 161-168.

D o m s c h K. H, G a m s W, A a d e r s o n T. H. 1980. Compendium of soil fung. London, New York, Toronto, Sydney, San Francisco: Acad. Press

D a g a a F. M. G 1 o v c G. G. R o g c r \& J. D. 1993. Comparative stadies of Cryptosporiopsis curvispora and $C$. perennans. 1. Morphology and pathogenic behaviour. Mycologia 85: $551-564$.

D u m as M. T. 1992 Inhibition of Armillaria by bacteria isolated from soils of the Boreal mixedwood Forest of Ontario. Eur. J. For. Pathol. 22: 11-18.

G a r fe: t S. D. 1956. Rhizomorph bohaviour in Armillaria mellea (Vah) Quel., Il. Logistics of infection. Ann. Bot. 20: 193-209.

G o c b e n a u r S. E. 1978. Fungi of a Long Island oak-birch forcst I. Community organization and seascnal oceurrence of the opportunistic decomposers of the A horizon Mycologia 70 : 975-994.

G o c b e n a u r S. E. 1984. Fungi of a Long Island oak-birch forest II. Population dynamics and bydrolase patterns for the soil Penicillia. Mycologia 76: 218-231.

G o c hen a u r S E, B a cku \& M. P. 1967. Mycology of willow and cottonwood lowland communities in southern Wisconsin. 11. Soil microfungi in the sandbar willow stands. Mycologia 59: $893-901$.

Goc he n a e S. E, W o o d w e I/G. M. 1974. The soil microfungi of a chronically irradiated oak-pine forest. Ecology 55: 1004-1016.

G uilla u m in J. J, L u a g B. 1985. Etude de la specialisation d' Armillaria mellea (Vahl) Kumm. et Armillarie obsctira (Secr.) Herink en phase saprophytique et en phase parasitaire. (Study of the specialization of Armillaria mellea (Vahl) Kumm. and Armillaria obscura (Secr.) Herink in the saprophytic phase and in the parasitic phase.) Eur. J. For. Pathol. 15: 342-349.

Guillaumin J. J, Mobammed C, Ansel mi N, Courtecaisse R., Gre. gory S. C. Holdentieder $O_{2}$ Intiai M. Lung B., Marxmaller H., Morrisoa D., Rishbeth J. Termorshuizen A. J., Titro A., Van D a m B. 1993. Geographical distribution and ecology of the Armillaria species in western Europe. Eur. J. For. Pathol 23: $321-341$.

G u ill a u m i n J. J., R y k ow s k i K. 1980. Studium infekcji orcecha wloskiego (Juglans regia L) przez opienke miodową (Armillaria mellea (Vahl) Quel.) w warunkach doswiadecenia modelowego. [Study of infection of walnut (Jugians regia L.) by honey fungus (Armillaria mellea (Vahl) Quel.) in model experiments.] Fol. Forest. Pol. 24: 191-213.

H a g I c S. K., S h a w C. G. 1991. Aroiding and Reducing Losses from Armillaria Root Discase. In: C. G. S h a w, G. A. K i le (eds), Armillaria Root Disease. USDA Forest Service. Washington. Agriculture Handbook 691: 157-173.

H a $\mathrm{r}$ l e y J. L, W a id J. S. 1955. A method of studying active mycelia on living roots and other surfaces in the soil. Trans. Br. Mycol. Soc. 38: 104-118.

Holdentieder O., S i c be: T. N. 1992. Fungal associations of serially washed healthy non-mycorrhizal roots of Picea abies. Mycol. Res. 96: 151-156.

K i I c G. A., M c D o n a I d G. 1. B y I e W. 1991. Ecology and disease in natural forests. In: C. G. S b a w, G. A. K i I e (eds), Armillaria Root Disease. USDA Forest Service. Washington. Agriculture Handhook 691: 102-121.

$\mathrm{K}$ ow a $15 \mathrm{k}$ iS. 1982. Role of mycorrhiza and soil fungi in natural regeneration of fir (Abies alba Mill.) in Polish Carpathians and Sudetes. Eur. J. For. Pathol. 12: 107-112.

K o w a Is k i T. 1991. Oak decline 1. Fungi associated with various disease symptoms on overground porions of middle-aged and old cak (Quercus robur L). Eur, J. For. Pathol. 21: $136-151$.

K ow a Is k i T., B a r t n i k C. 1995. Cryplosporiopsis radicicala sp. nov, from roots or Quercus nobur. Myc Res, 99: 663-666.

$\mathrm{K}$ ow a is $\mathrm{k} \mathrm{i}$ T, K e h r R. D. 1992. Endophytic fungal colonization of branch bases in several forest tree species. Sydowia 44: 137-168. 
K r zem ie n i ew s k a H. B a d u r a L. 1954. Z badań nad mikoflora lasu bukowego. [Some observation on the mycollora of beech woods] Acta. Soc. Bot. Pol. 23: 545-587.

$\mathrm{K} w$ a $s$ n a H. 1995. Fungal communities in soil beneath Scots pine and their stumps. Effect of fungi on Helerabasidion annosum and Armillaria astoyae growth. Acta MycoL. 30: 193-205.

$\mathrm{K}$ w a $5 \mathrm{n}$ a H. 1996 a. Mycobionta of birch and birch stump roots and its possible effect on the infection by Armillaria spp. L Acta Myeol. 31: 101-110.

$\mathrm{K}$ w a $5 \mathrm{n}$ a H. $1996 \mathrm{~b}$. Mycobionta of birch and birch stump roots and its possible effect on the infection by Armillaria spp. II. Acta Mycol. 31: 111-122.

K w a in a H. 1997 a. Antagonistic effect of fungi communities from Seots pine roots on Heterobasidion annosum (Fr) Bref. and Amillaria osioyae (Romagn.) Herink. growth. Phytopathol. Pol. 13: 133-146.

K w a s n a H. 1997 b. Antagonistic effect of fungi from Scots pine stump roots against Heterobasidion cunosum and Amillaria ostoyae. Acte. Mycol 32; 369-381.

$\mathrm{K}$ w a $\$ \mathrm{n}$ a H. $1997 \mathrm{c}$. Fungi on the surface of roots of Scois pine and its stumps and their effect on Heterobasidian annosum (Fr.) Bref. and Arniliaria ostoyae (Romagn.) Herink growth. Pol. Agric. Ann, E. E, 28. 1/2: $109-123$.

$\mathrm{K}$ w a s $\mathrm{n}$ a H., L a k a m y P. 1998. Stimulation of Armillarin estoyae vegetative growth by tryptophol and rhizomorph produced by Zygorhynchus moelleri. Eur. J. For. Pathol. 28: $53-61$.

L a r s $s$ o $B$. 1998. The toxicology and pharmacology of melanins. In; J. J, N o r d 1 u n d, R. E. B o i s 5 y, V. J. H e a r i g g. R. A. K i n g, J.-O. O r t o n n e (eds), The pigmentary system. Oxford, UK: Oxford Univ. Press: $373-389$.

L e v i s o h n I. 1960. Physiological and ecological factors influencing the effects of mycorthizal inoculation. New Phytol. 59: 42-47.

L i n h e II D. 1939. Untersuchungen über die Mykorrhizen und die Wurzelpilac von Juniperus communis. Symb. Bot. Ups. 3: $1-141$.

L. ivings to n e W. H., B I a $5 \mathrm{c}$ h k e H. 1984. Deterioration of mycorrhizal short roots and occurrence of Mycelium radicis airowirens on dectining Norway spruce in Bavarie. Eur. J. For. Pathol. 14: $340-348$.

L a k om y P. 1996. Zdolność produkcji ryzomorf przaz ró́ne genotypy Armillaria osroyae (Romagn.) Herink. [Rhizomorph production by Armillarie ostoyae different genotypes.] In: M. M a n ka (eds), Choroby roslin a stodowisko. Poznan: Polish Phytopath. Soc. Press: $145-153$.

M a á $\mathrm{k}$ a K. 1953. Badania terenowe i laboratoryjne nad opicńk 4 miodowa - Armillaria mellea (Vahl) Quel. [Forest and laboratory studies on the honey fungus - Armillaria meilea (Vahl) Quel.] Prace IBL. 94:1-96.

M a ń k a K. 1960 O grzybic korzeniowym Myceliun radicls atrovirens Melin. (Der Wurzelpilz Mycelium radicis atrovirens.) Monog. Bot. 2: 147-15B.

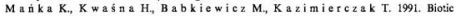
resistance of soil to plant pathogens. In: A. B. R. Be emster, G. L. B olle $\mathrm{n}, \mathrm{M}$. Gerlag h, M. A. Ruissea, B. S ch i p pers, A. T e m pel (eds), Biotic interactions and soil-borne diseases. Proceed. of the first Conference of the European Foundation for Plant Pathology. Elsevier $311-315$.

M a ák a K., G i e r c za k M., P r u s i a k i e w i c z Z. 1968. Zamieranie siewek cisa (Taxus baccala L.) $w$ Wierzchlesie na tle zespolbw saprofitycznych grzybów irodowiska glebowego. [The succumbing of yew-tree seedlings in Wierzchlas and the saprophytic fungi of the soil environment.] PTPN. Prace Kom. Nauk Roln. Kom. Nauk Leśn. 25: 177-19s.

M a á k a K., T r u s z k o w s k a W. 1958. Próba mikologicznej analizy korzeni świerka (Picea excelsa Lk.). (Versuch einer mykologisehen Analyse von Fichtenwurzeln Picea excelsa Lk.). Acta. Soc, Bot. PoL 27; $45-73$

Meli n E. 1921. Uber die Mykorthizapilze von Pinus silvestris L. und Piceu abies (L.) Karst. (vorlaufige Mitteilungen), Sven. Bot. Tidsk. 15: 192-203. 
Meli n E. 1923. Experimentalle Uatersuchungen über dic Konstitution und Okologie der Mykorthizen ron Pinus silvestris L. und Picea abies (L.) Karst. Myk. Unter. Ber. 2: 73-331.

Mor r a 11 R. A. A. 1974. Soil mictofung. associated with aspen in Saskatchewan: synecology and quantitative analysis. Can. J. Bot. 52: 1803-1817.

M orra 11 R. A. A. V a n t c p po IT. C. 1968. The soil microfungi of upland boreal forest at Candle Lake, Saskatchewan. Mycologia 60: 642-654.

M o t $t$ a J. J. 1969. Cytology and morphogenesis in the rhizomorph of Armillaria mellea. Amer. J. Bot 56: $610-619$.

$\mathrm{Nircaberg} \mathrm{H.} \mathrm{1976.} \mathrm{Untersuchungen} \mathrm{bet} \mathrm{die} \mathrm{morphologische} \mathrm{und} \mathrm{biologische} \mathrm{Differen.}$ zierung in der Fusarium - Section Liseola. Mitt. Biol. Bundes. Land- Forst. Berlin-Dahlem 169: $1-117$,

Norak R. O., Whitting ha m W. F. 1968. Soil and litter microfungi of a maple-elm-ash floodplain community, Mycologia 60: 776-787.

Ota Y, Matsushita N., Nagasawa E, Tetashita T, Fukuda K, S u zuki K. 1998. Biological species of Armillaria in Japan. Plant. Dis, 82: 537-543.

Pe $t 1$ a nd G. D. 1965. Stimulation of rhizomorph development of Armillaria mellea by Aureobasidium pulluians in artificial culture. Can. J. Microb. 11: $345-350$.

P e n I I a n d G. D. 196?. Ethanol produced by dureobaridium pullulens and its effect on the growth of Armillaria mellea. Can. J. Microb. 13: 1631-1639.

Przez bor s X i A, K w a $\$$ n a H. 1989. Mikchlora dębów iśfodowiska glebowego w drzewostanach $z$ objawami epidemicznego zamierania drzew. [Mycollora of oaks and soil biotop in the tree stands with symptoms of the epidemic extinction of trees]. Akademia RolniczoTechniczna, Bydgoszez. Zesz. Nauk.159: 87-94.

R ed fe r n D. B. 1973. Growth and behaviour of Amillaria mellea thizcmorphs in soil. Trans. Be. Myc. Soc. 61: 569-581.

Red fer a B, F i I i p G. M. 1991. Inoculum and Infection. In: C. G. S h a w, G. A. K i I e (eis). Armillaria Root Disease. USDA Forest Service. Washington: Agrieulture Handbook 691: $48-62$.

Richard C, Forti n J. A. 1974. Distribution geographicque, ecologic, physiologic, pathogenicite et sporulation du Mycelium radicis atrovirens. Phytoprotection 55: 67-88.

$\mathbf{R}$ is b b e 1 b J. 1985 a. Infeetion cycle of Amillaria and host response. Eur. J. For Path. 5: $332-341$.

R i s h be t h J. 1985 b. Armallaria: resources and hosts. In: D. M 0 o r e, L. A. C a s s e I t o n, D. A. W o o d (eds), Developmental biology of higher fungi. Cambridge: Cambridge Univ. Pross: $87-101$.

R o berts on N. F. 1954. Studies on the mycorrhiza of Pinus syivestris. 1. The pattem of development of mycorshizal roots and its significanoe for experimental studies. New Phytol. 3: $253-283$.

R oll- $\mathrm{H}$ a n s e F. 1985. The Armillaria species in Europe. A literature review. Eur. J. For. Pathol. 15: $22-31$.

R y k ow $\$$ k i K. 1984. Niektore troficzne uwarunkowania patogeniczności Armillaria mellea (Vahi) Quel. w upra wach sosnowych. [Some trophic factors in the pathogenicity of Armillaria mellea in Scots pine plantations]. Prace IBL 640: 1-40.

$\mathrm{S}$ a mpo S., Bergoro R., Buffa G., L uppi-M osca A. M, 1997. Soil fungal communities in a young and an old Alnus viridis coenosis. Mycologia 89:837-845.

$\mathrm{S}$ a $\mathrm{m}$ u e I $5 \mathrm{G}$. J. 1988 . Species of Nectria (Ascamyceies, Hypocreales) having orange perithecia and colorless, striate ascospores. Brittonia 40.306-331.

$\mathrm{S} \mathrm{ch}$ ild D. E, Ke a ti ed y A, S t u a I t M. R. 1988. Isolation of symbiont and associated fungi from ectomycorrhizas of sitka spruce. Eur. J. For. Path. 18. 51-61.

S chroe es H. J., S a mue 1s G. J, S ifert K. A, G a ms W. 1999. Classification of the mycoparasite Gliocladium roseum in Clonostachys as C. rosea, its relationship to Bionectria ochroleuca, and notes on other Gliocladium-like fungi. Mycologia 91: 365-385. 
S i e p m a n n V O R. 1985. Uber das Vorkommea von Amillaria-Arten und -Klonen in benachbarten Koniferenbestinden, Mischbeständen und in Laubwald. Eur. J. For. Path. 15: $71-80$.

S i g m a Stat. 2995. Jandel Corporation. San Rafael. California.

S u m merbe11 R. C. 1989. Microfungi associated with the mycorrhizal mantle and adjecent micrchabitats within the rhirospbere of black spruce. Can J. Bot. 67: 1085-1095.

$\mathrm{S}$ u $t$ t o n B. C. 1992. The Coelomycetes. Fungi Imperfecti with Pycnidia, Acervuli and Stromats. CMI. Kew, U.K.

T o w n s e n B B. 1954. Morphology and devclopment of fungal thizomorphs. Trans. Br. Mye. Soc. 37: $222-233$.

W a n g C. J. K, W i / e o x H. E. 1985 . New species of ectendomycorrhizal and pseudomycorrhizal fungi: Phialoghora finlandia. Chloridium paucisporum, and Phialocephala fortinï. Mycologia 77: $951-958$.

W a r g o P. M, H a r r in g t o n T. C 1991. Hest stress and susceptibility. In. C. G. S b a w, G. A. K i l e (eds), Amillaria Root Disease. USDA Forest Service. Washington: Agriculturel Handbook 691: 88-101.

W a I g o P. M., S h a $\approx$ C. G. 1985. Armillaria root rot: The puzzle is being solved. Plant Dis. 69: $826-832$

W a $t$ a n a b e T. 1986. Rhizomorph production in Armillaria mellea in vitro stimulated by Macrophoma sp. and several other fungi Trans. Myc. Soc. Jap. 27: 235-245.

W i ck l ow M C, B o II e n W. B., Den is o n W. C. 1974. Comparison of soil microfungi in 40-year-old stands of pure alder, pure conifer, and alder-eonifer mixtures. Scil. Biol. Bioch. 6: $73-78$.

Z ó ł c i a k A. 1999 a. Identyfikacja gatunków grzybów z rodzaju Armillaria (Fr: Fr.) Staube w Polsce. [Idcntification of species of the Armillaria (Fr.:Fr.) Staube genus in Poland.] Prace IBL. 888: $3-19$.

Z ó ł c i a K A. 1999 b. Występowanie grzybów z rodzaju Armillaria (Fr.: Fr.) Staube w kompleksach lesinych w Polsce. [The occurrence of species from the Armillaria (Fr.Fr.) Staube genus in forests in Poland.] Prace 1BL 890: 29-40.

Stymulacja wzrostu ryzomorf Armiliaria przez grzyby z korzeni dębu

$$
\text { Streszezenie }
$$

Z drewna korzeni 50-letniego dębu szypułkowego (Quercus robur) wizolowane 31 gatunków mikrogrzybów. Najczęściej wystẹpowały Mycelium radicis atrovirens alpha, Clonostachys sp. i Penicillium daleac. Beauveria bassiana, Clonostachys sp, Cryptosporiopsit radicicela, Geourichum candidum, Martierella vinacea, Mycelium radicis atrovirens alpha, $P$, daleoe, $P$. janczewskii, $P$. spinulasum, Sporothrix schenckil i Tolypocladilun nireum stymulowaty istotnje powstawanic i wzrost ryzomorf Armillaria mellea w drewnic dębowym in vitro. Największy efekt stymulujqcy obserwowano w testach z grzybami ciemnozabarwionymi: MRAA, Phialocephala dimorphospona i Sporothrix schenckii. 